\title{
Therapy of Localized Esophageal Cancer: It Is Time to Reengineer Our Investigative Strategies
}

\author{
Jaffer Ajani \\ Department of Gastrointestinal Medical Oncology, The University of Texas M. D. Anderson Cancer Center, The University of Texas, \\ Houston, TX, USA
}

The incidence of esophageal cancer has risen by $>40 \%$ in the United States in the past 20 years (www.cancer.org accessed April 8, 2008). It is due to the dramatic increase in the incidence of adenocarcinoma [1] but this rise is palpably more profound in England and Scotland (http://info. cancerresearchuk.org/cancerstats/types/oesophagus/ accessed April 14, 2008). Increasing body mass index, gastroesophageal reflux disease, Barrett's esophagus, and many unknown factors may be at the root of this increase. Although men are afflicted frequently with adenocarcinoma, women are not too far behind. Esophageal cancer is often diagnosed in a late stage (stage 2 or higher) and the 5-year survival rates with surgery or definitive chemoradiation have been at a stand still for decades $[2,3]$. The use of surgery as primary therapy has diminished and the use of preoperative therapy, particularly preoperative chemoradiation has become the norm in the USA despite equivocal results [4-8]. Investigators interested in esophageal cancer have been busy adding newer classes of cytotoxics to fluorouracil over some time now. The commonly used classes of cytotoxics for preoperative therapy are fluoropyrimidine, taxane, camptothecin, and platinum. These drugs are added or removed from further investigation based solely on empiricism; we finish the trial and get disappointed as usual. None of us has a clue as to what combination is better and until we do, perhaps we should choose the ones that are well tolerated [9]. Blinded use of targeted agents cannot quench our desire for rapid progress because the targeted agents act only if certain alterations exist within the tumor [10,11].

We set our endpoints for the entire cohort of patients and look for treatment effect. This technique might have been modern in the past but now we have a greater realization of heterogeneous outcomes in individual patients receiving the same therapy. We know that some patients do not benefit from chemotherapy, some do not benefit from radiation therapy, and some do not benefit from surgery. Chemoradiation
[12] and surgery [13] can result in considerable morbidity and/or mortality. Why do we subject every patient to all these modalities? It is not because we cannot be creative. It may be because we cater to traditions and because change is hard to implement.

The clinical biology (prognosis and response to therapy (prediction)) is ingrained in the genomic and epigenomic make up of the individual cancer $[14,15]$. The rapid progress in our understanding of molecular alterations that drive cancer cells has been fueled by advances in genomic technologies, computational sciences, and collaborative spirits between clinicians and basic scientists working in various disciplines [15]. Further understanding will doubtless lead to identification of therapies that target distinct molecular abnormalities of importance and pave the path to the individualized care of patients. Our current understanding of molecular biology of esophageal cancer is very superficial and lagging far behind common western tumors. It may, however, be possible to borrow the knowledge generated in other tumor types [14]. For example, we could exploit the knowledge gained from an in-depth study that identifies an active treatment because a certain pathway is activated and then use the same treatment for esophageal cancer if it has the same pathway activated [16].

Until we achieve that level of sophistication, we could lean on imaging studies that might allow us to stop therapies that are ineffective $[17,18]$ and gain enhanced understanding of the potentially effective ones. More sophisticated imaging techniques might be even more useful in optimizing therapy [19, 20]. Eventually molecular biology and more specific imaging techniques will complement each other.

In this issue of ONKOLOGIE, a highly recognized group in gastroesophageal cancer research reports their experience with paclitaxel as part of preoperative combination chemotherapy. Bader et al. [21] report on an analysis of 67 esophageal adenocarcinoma patients treated in two sequential trials. 32 of 67 pa-

\begin{tabular}{|c|c|}
\hline KARGER & (c) 2008 S. Karger GmbH, Freiburg \\
\hline $\begin{array}{l}\text { Fax +49 } 7614520714 \\
\text { E-mail Information@Karger.de } \\
\text { www.karger.com }\end{array}$ & $\begin{array}{l}\text { Accessible online at: } \\
\text { www.karger.com/onk }\end{array}$ \\
\hline
\end{tabular}

Jaffer A. Ajani, M.D.

Department of Gastrointestinal Medical Oncology

The University of Texas M. D. Anderson Cancer Center

1515 Holcombe Blvd. (Mail stop 426), Houston, TX 77030, USA

Tel. +1 713-792-2828

E-mail jajani@mdanderson.or 
tients were treated with fluorouracil and cisplatin and 35 were treated with paclitaxel, fluorouracil, and cisplatin. The authors found that, although clinical response was higher in the paclitaxel group $(p=0.04)$, the histopathologic response and overall survival were not statistically different. They correctly conclude that the addition of paclitaxel failed to improve the outcomes. Limitations of this report include: comparison of nonrandomized populations, retrospective nature of the analysis, small number of patients, patients treated in different time frames, and investigator bias. However, their data are consistent with a recent publication from the Duke University on 109 patients [22] and 180 patients from my center [9]. On the other hand, in another unpublished analysis of $360+$ patients from my center, the use of a taxane in patients with localized carcinoma of the esophagus treated with preoperative chemoradiation lead to a survival advantage. All these reports are somewhat limited by their sample size and their retrospective nature. Such findings need prospective validation, of course. However, they are not inconsistent with our knowledge of docetaxel in advanced gastroesophageal cancer where it does prolong patient survival [23]. If one wants definitive answers, having an appropriate sample size is one of the essential elements.

What should we do next? I think it is time to reengineer our entire approach to therapeutic investigations. Esophageal cancer tissue is easily accessible and assessing genomic/ epigenomic alterations should not be technically difficult. It is nevertheless a laborious, lengthy, and costly endeavor. We need to divert resources to identify predictive biomarkers and/or imaging parameters to help develop personalized care of these patients. One institution cannot hoe the row, therefore, we should develop collaborations among ourselves that emphasize translational research. The idea of recommending the same treatment to every patient, when only a few might benefit and everyone would experience toxic effects, is quickly slipping out of my mind.

\section{References}

1 Pohl H, Welch HG: The role of overdiagnosis and reclassification in the marked increase of esophageal adenocarcinoma incidence. J Natl Cancer Inst 2005;97:142-146.

2 Jemal A, Siegel R, Ward E, Hao Y, Xu J, Murray T, Thun MJ: Cancer statistics, 2008. CA Cancer J Clin 2008;58:71-96.

3 Cooper JS, Guo MD, Herskovic A, Macdonald JS, Martenson JA, Jr., Al-Sarraf M, Byhardt R, Russell AH, Beitler JJ, Spencer S, Asbell SO, Graham MV Leichman LL: Chemoradiotherapy of locally advanced esophageal cancer: long-term follow-up of a prospective randomized trial (rtog 85-01). Radiation therapy oncology group. JAMA 1999;281: 1623-1627.

4 Tepper J, Krasna MJ, Niedzwiecki D, Hollis D, Reed CE, Goldberg R, Kiel K, Willett C, Sugarbaker D, Mayer R: Phase III trial of trimodality therapy with cisplatin, fluorouracil, radiotherapy, and surgery compared with surgery alone for esophageal cancer: Calgb 9781. J Clin Oncol 2008; 26:1086-1092.

5 Bosset JF, Gignoux M, Triboulet JP, Tiret E, Mantion G, Elias D, Lozach P, Ollier JC, Pavy JJ, Mercier M, Sahmoud T: Chemoradiotherapy followed by surgery compared with surgery alone in squamous-cell cancer of the esophagus. N Engl J Med 1997;337:161-167.

6 Walsh TN, Noonan N, Hollywood D, Kelly A, Keeling N, Hennessy TP: A comparison of multimodal therapy and surgery for esophageal adenocarcinoma. N Engl J Med 1996;335:462-467.

7 Urba SG, Orringer MB, Turrisi A, Iannettoni M, Forastiere A, Strawderman M: Randomized trial of preoperative chemoradiation versus surgery alone in patients with locoregional esophageal carcinoma. J Clin Oncol 2001;19:305-313.

8 Suntharalingam M, Moughan J, Coia LR, Krasna MJ, Kachnic L, Haller DG, Willet CG, John MJ, Minsky BD, Owen JB: Outcome results of the 1996-1999 patterns of care survey of the national practice for patients receiving radiation therapy for carcinoma of the esophagus. J Clin Oncol 2005;23: 2325-2331.
9 Javeri H, Arora R, Correa AM, Hofstetter WL, Lee JH, Liao Z, McAleer MF, Maru D, Bhutani MS, Swisher SG, Izzo JG, Ajani JA: Influence of induction chemotherapy and class of cytotoxics on pathologic response and survival after preoperative chemoradiation in patients with carcinoma of the esophagus. Cancer 2008; in press.

10 Mellinghoff IK, Wang MY, Vivanco I, Haas-Kogan DA, Zhu S, Dia EQ, Lu KV, Yoshimoto K, Huang JH, Chute DJ, Riggs BL, Horvath S, Liau LM, Cavenee WK, Rao PN, Beroukhim R, Peck TC, Lee JC, Sellers WR, Stokoe D, Prados M, Cloughesy TF, Sawyers CL, Mischel PS: Molecular determinants of the response of glioblastomas to egfr kinase inhibitors. N Engl J Med 2005;353:20122024.

11 Sharma SV, Bell DW, Settleman J, Haber DA: Epidermal growth factor receptor mutations in lung cancer. Nat Rev Cancer 2007;7:169-181.

12 Ajani JA, Winter K A, Komaki R, Kelsen D P, Minsky B D, Liao Z, Bradley J, Fromm M, Hornback D, Willett C G: A phase II randomized trial of two non-operative approaches of induction chemotherapy followed by chemoradiation in patients with localized carcinoma of the esophagus. The radiation therapy oncology group 0113 study. J Clin Oncol 2008; in press.

13 Kelsen DP, Ginsberg R, Pajak TF, Sheahan DG, Gunderson L, Mortimer J, Estes N, Haller DG, Ajani J, Kocha W, Minsky BD, Roth JA: Chemotherapy followed by surgery compared with surgery alone for localized esophageal cancer. N Engl J Med 1998;339:1979-1984.

14 Sawyers CL: The cancer biomarker problem. Nature 2008;452:548-552.

15 Chin L, Gray JW: Translating insights from the cancer genome into clinical practice. Nature 2008; 452 : 553-563.

16 Bild AH, Yao G, Chang JT, Wang Q, Potti A, Chasse D, Joshi MB, Harpole D, Lancaster JM, Berchuck A, Olson JA, Jr., Marks JR, Dressman HK, West M, Nevins JR: Oncogenic pathway signatures in human cancers as a guide to targeted therapies. Nature 2006;439:353-357.
17 Ott K, Herrmann K, Lordick F, Wieder H, Weber WA, Becker K, Buck AK, Dobritz M, Fink U, Ulm K, Schuster T, Schwaiger M, Siewert JR, Krause BJ: Early metabolic response evaluation by fluorine-18 fluorodeoxyglucose positron emission tomography allows in vivo testing of chemosensitivity in gastric cancer: Long-term results of a prospective study. Clin Cancer Res 2008;14:2012-2018.

18 Lordick F, Ott K, Krause BJ, Weber WA, Becker K Stein HJ, Lorenzen S, Schuster T, Wieder H, Herrmann K, Bredenkamp R, Hofler H, Fink U, Peschel C, Schwaiger M, Siewert JR: PET to assess early metabolic response and to guide treatment of adenocarcinoma of the oesophagogastric junction: The municon phase II trial. Lancet Oncol 2007;8: 797-805.

19 Weissleder R, Pittet MJ: Imaging in the era of molecular oncology. Nature 2008;452:580-589.

20 Apisarnthanarax S, Alauddin MM, Mourtada F, Ariga H, Raju U, Mawlawi O, Han D, Bornmann WG, Ajani JA, Milas L, Gelovani JG, Chao KS: Early detection of chemoradioresponse in esophageal carcinoma by 3'-deoxy-3'-3h-fluorothymidine using preclinical tumor models. Clin Cancer Res 2006;12:4590-4597.

21 Bader FG, Lordick F, Fink U, Becker K, Hofler H, Busch R, Siewert J R, Ott K: Paclitaxel in the neoadjuvant treatment for adenocarcinoma of the distal esophagus. A comparison of two phase II trials with long-term follow-up. Onkologie 2008;31: 366-372.

22 Kelsey CR, Chino JP, Willett CG, Clough RW, Hurwitz HI, Morse MA, Bendell JC, D'Amico TA, Czito BG: Paclitaxel-based chemoradiotherapy in the treatment of patients with operable esophageal cancer. Int J Radiat Oncol Biol Phys 2007;69:770776.

23 Van Cutsem E, Moiseyenko VM, Tjulandin S, Majlis A, Constenla M, Boni C, Rodrigues A, Fodor M, Chao Y, Voznyi E, Risse ML, Ajani JA: Phase III study of docetaxel and cisplatin plus fluorouracil compared with cisplatin and fluorouracil as firstline therapy for advanced gastric cancer: A report of the v325 study group. J Clin Oncol 2006;24:49914997. 